\title{
Sciatic neuropathy developed after injection during curettage
}

\author{
Küretaj sırasında enjeksiyon sonrası ortaya çıkan siyatik nöropati
}

\author{
Ayşe ALTINTAŞ, ${ }^{1}$ Ayşegül GÜNDÜZ,' Fatih KANTARCl, ${ }^{2}$ Gökçen GÖZÜBATIK ÇELiK,' \\ Naci KOÇER, ${ }^{2}$ Meral E. KIZILTAN'
}

\begin{abstract}
Summary
Intramuscular injections are likely the most common cause of sciatic nerve injury in developing countries. Less common causes include piriformis syndrome, primary tumors of the sciatic nerve, metastatic tumors invading or compressing the nerve, endometriosis, vascular malformations, and prolonged immobilization or positioning. While the most reliable diagnostic and prognostic methods include nerve conduction studies and electromyography, magnetic resonance imaging has been suggested as an alternative method of determining type of lesion, establishing location, and investigating level of nerve involvement. A case of sciatic neuropathy that developed after intramuscular injection, with patient in prolonged lithotomy position and under sedation, is described.
\end{abstract}

Keywords: Electrophysiology; magnetic resonance imaging; sciatic neuropathy.

\section{Özet}

Kas içi enjeksiyonlar, gelişmekte olan ülkelerde siyatik sinir hasarının en sık nedenidir. Piriformis sendromu, siyatik sinir primer tümörleri, sinire invazyon ya da bası yapan metastatik tümörler, endometriyozis, vasküler malformasyonlar, uzamış immobilizayon veya spesifik pozisyonlar daha nadir siyatik nöropati nedenleridir. En güvenilir tanı yöntemleri sinir ileti incelemeleri ve elektromiyografi olmakla birlikte manyetik rezonans görüntülemenin lezyon tipini belirlemek, lezyon bölge ve seviyesini kesinleştirmekte alternatif inceleme yötemi olduğu ileri sürülmektedir. Burada, sedasyon altında uzun süreli litotomi pozisyonunda kas içi enjeksiyon sonrasında gelişen siyatik nöropati olgusu sunmaktayız.

Anahtar Kelimeler: Elektrofizyoloji; manyetik rezonans görüntüleme; siyatik nöropati.

\section{Introduction}

Sciatic nerve is vulnerable to trauma like fracture, dislocations, hematomas, intramuscular injections and complications of hip replacement surgery. ${ }^{[1]}$ Intramuscular injections seem to be the most common causes of sciatic nerve injury in developing countries. Piriformis syndrome, primary tumors of sciatic nerve, metastatic tumors invading or compressing the nerve, endometriosis, vascular malformations, prolonged immobilization or specific positions are rarer causes of sciatic neuropathy. In any case with symptoms attributed to the sciatic neuropathy, the most reliable assessment methods are nerve conduction studies and electromyography (EMG) for di- agnosis and prediction of prognosis. ${ }^{[2]}$ However, with the development of new neuroimaging techniques and improvement of the present ones, using magnetic resonance imaging (MRI) or ultrasonographic investigations (USG) in peripheral nerve diseases are increasing. MRI is also suggested to be an alternative investigation method to determine the type of lesion, to establish its site and the level of nerve involvement. ${ }^{[3]}$

Here, we aim to present clinical and radiological findings of a case with sciatic neuropathy which developed after intramuscular injection during a prolonged lithotomy posture.

\footnotetext{
'Department of Neurology, Istanbul University Cerrahpasa Faculty of Medicine, Istanbul, Turkey ${ }^{2}$ Department of Radiology, Istanbul University Cerrahpasa Faculty of Medicine, Istanbul, Turkey

Submitted: 16.03.2014 Accepted after revision: 01.09.2014
}

Correspondence: Dr. Ayşegül Gündüz. İstanbul Üniversitesi Cerrahpaşa Tıp Fakültesi, Nöroloji Anabilim Dalı, 34098 Fatih, İstanbul, Turkey. Tel: +90 - 212 - 4143165 e-mail: draysegulgunduz@yahoo.com

(C) 2016 Turkish Society of Algology 


\section{Case Report}

A 25-year-old woman admitted to our outpatient clinic with pain, numbness and tingling on the plantar surface of the right foot. All findings had developed 2 months ago immediately after gluteal injection of diclofenac sodium at the end of approximately 1-hour long curettage for hydatiform mole. She was also administered antibodies for Rh incompatibility via intramuscular route. She reported that she had numbness and tingling on the plantar surface of last three fingers of right foot which spread out to the heel within minutes after the injection. In the same day, unbearable, shock like pain in the same territory developed. She was given nonsteroid analgesics and $2400 \mathrm{mg} /$ day gabapentin for pain before the admission to our clinic with no improvement. She had history of Familial Mediterranean Fever and was using colchicine for 10 years. Neurological examination showed hypoesthesia, paresthesia and allodynia in the territory of peroneal nerve. Inversion, eversion as well as dorsal and plantar flexion of foot, all hip and knee movements were normal. All deep tendon reflexes were normoactive except hypoactive right Achilles reflex. Plantar response was bilaterally flexor.

Differential diagnosis included sciatic neuropathy and lumbar radiculopathy, she had undergone lumbar MRI and then hip MRI which showed hyperintensity and enhancement of bilateral sciatic nerves predominantly on the right side affecting longer segment and she was referred to our clinic. We performed EMG and confirmed sciatic neuropathy with decreased sural nerve and tibial nerve motor response amplitudes with relatively preserved latencies and conduction velocities. Needle EMG demonstrated neurogenic motor unit potentials with few spontaneous potentials (in the second month after the beginning of symptoms). Therefore, we concluded that she had partial axonal loss on the tibial division of sciatic nerve.

She was treated with intravenous $250 \mathrm{mg} /$ day methylprednisolone for five days followed by decreasing doses of oral methyl prednisolone. Pain and paresthesias started to decrease on the fifth day and they disappeared within a month. Neurological examination showed decreased allodynia. Last MRI findings on the 10th day of admission were thicker and denser sciatic nerve on the right side starting from sciatic
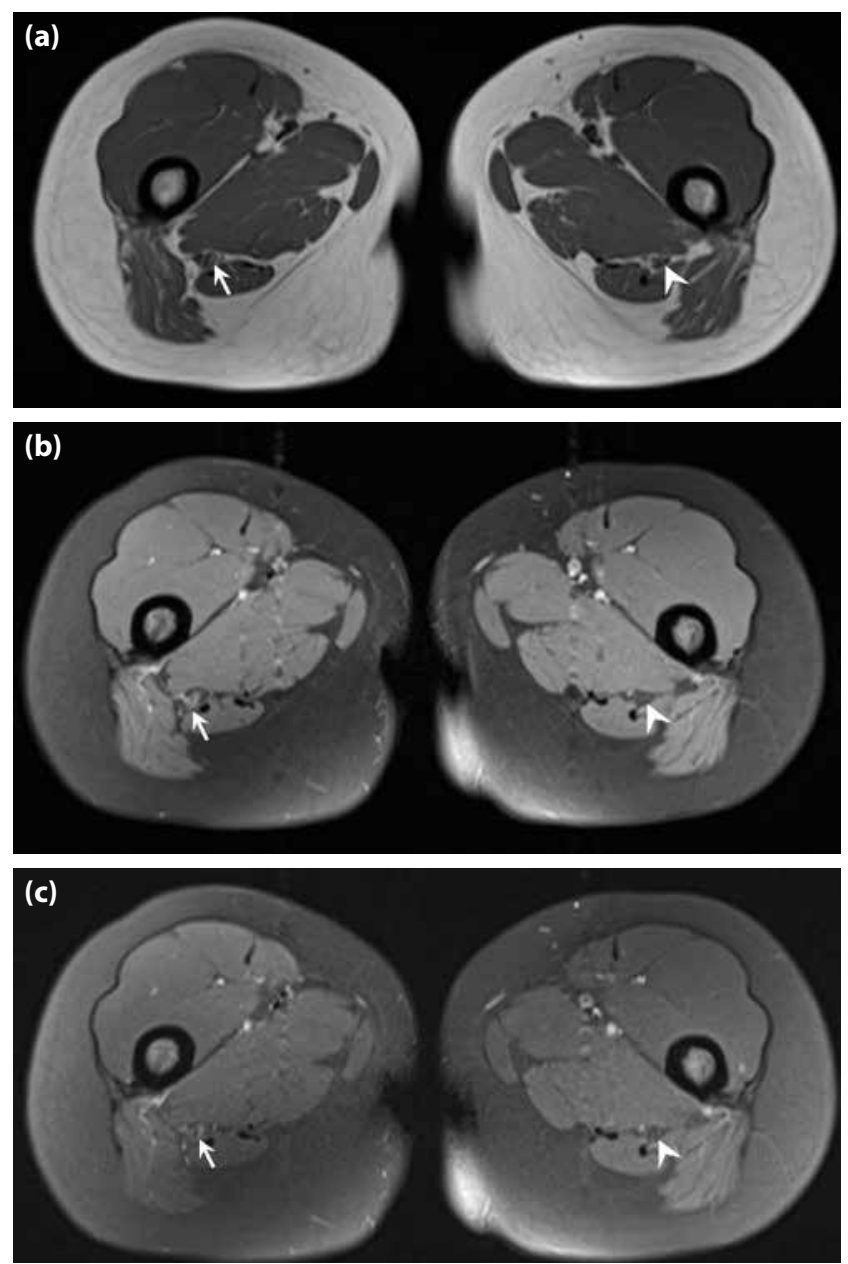

Figure 1. (a) Axial T1 weighted MRI at proximal thigh level shows enlargement of the right sciatic nerve (white arrow) when compared to the left sciatic nerve (white arrowhead). (b) Axial contrast enhanced fat suppressed T1 weighted MRI demonstrates enhancement of the right sciatic nerve (white arrow). Note the normal left sciatic nevre (white arrowhead). (c) Axial fat suppressed proton density weighted MRI shows increased signal intensity of the right sciatic nerve (white arrow). The normal left sciatic nerve (white arrowhead) is homogenously hypointense in appearance.

tubercle and ending at the popliteal fossa. On T2 weighted images, nerve itself and gluteus maximus muscle on the same side were hyperintense indicating edema and inflammation with decreased contrast enhancement (Figure 1a-c). Her clinical finding totally improved in the third month, however, we could not repeat the MRI because of new pregnancy.

\section{Discussion}

Direct mechanical injury, compression injury due to hematomas/abscess formation or changed gluteal muscle anatomy after abovementioned causes have the major role in pathogenesis whereas chemical injury also plays a role in injection neuropathy. Rarer causes of sciatic neuropathy are piriformis syn- 
drome, primary tumors of sciatic nerve, ${ }^{[4]}$ metastatic tumors invading or compressing the nerve, ${ }^{[4]}$ endometriosis, ${ }^{[5]}$ vascular malformations. ${ }^{[6]}$ Prolonged immobilization, ${ }^{[7]}$ or specific positions especially associated with distinct operations ${ }^{[8,9]}$ since sciatic nerve is thick and less vulnerable to injury. Possible causal factors in our case were intramuscular injection, prolonged immobilization and positioning in the lithotomy position during curettage procedure. Injection and prolonged lithotomy position under sedation probably had a synergistic effect by both causing compartment syndrome and chemical irritation. Although she had symptoms of only right side, bilateral radiological involvement supports the role of positioning.

Hydatiform moles may occasionally invade uterus and surrounding tissues and may be listed as a possible cause in our case. Timing of the symptoms and clinical course decreased this possibility. MRI was performed to exclude other possible etiologies. Direct imaging of size, course and signal intensity of sciatic nerve is possible on MRI because it is thick and has abundant perineural fat. ${ }^{[3]}$ The nerve is identified to have intermediate signal intensity on T1-weighted images and mildly high signal intensity on fluid-sensitive images. High-resolution images demonstrate the distinct nerve fascicles arranged into two separate bundles, made up of the larger tibial division of the nerve and the more lateral and smaller peroneal division. The sciatic nerve can be followed through its way from the greater sciatic foramen to the distal thigh. Tumor, scar, edema or hematomas are relatively easily differentiated based on criteria similar for the other parts of body. Involving long segment of nerve relatively homogenously without affecting the surrounding muscles, vascular structures or connective tissue decreases the possibility of local invasion or hematological distant metastasis. MRI evidence of neuropathy includes deviation along its course, increased size, increased signal intensity and contrast enhancement. Swelling and edema around the sciatic nerve at the level of the ischial tuberosity were also reported in sciatic compression neuropathy. ${ }^{[8]} \mathrm{MRI}$ of intrinsic nerve tumors may resemble with abnormal thickening and enhancement. ${ }^{[4]}$ For that reason, we followed serial findings which supported our first hypothesis of compression neuropa- thy because increased signal intensity and contrast enhancement resolved even in a short period.

In conclusion, pregnancy increases the risk of compression neuropathies, sciatic neuropathy secondary to piriformis syndrome during pregnancy is rare cause of sciatic neuropathy. ${ }^{[10]}$ Prolonged lithotomy position under sedation should be avoided. Injections in these conditions further increases the risk probably by causing compartment syndrome and should also be avoided.

\section{Conflict-of-interest issues regarding the author- ship or article: None declared.}

\section{Peer-rewiew: Externally peer-reviewed.}

\section{References}

1. Plewnia C, Wallace C, Zochodne D. Traumatic sciatic neuropathy: a novel cause, local experience, and a review of the literature. J Trauma 1999;47(5):986-91.

2. Kimura J. Peripheral nerve diseases. Amsterdam: Elsevier; 2006.

3. Petchprapa CN, Rosenberg ZS, Sconfienza LM, Cavalcanti $C F$, Vieira $R L$, Zember JS. MR imaging of entrapment neuropathies of the lower extremity. Part 1. The pelvis and hip. Radiographics 2010;30(4):983-1000.

4. McMillan HJ, Srinivasan J, Darras BT, Ryan MM, Davis J, Lidov HG, et al. Pediatric sciatic neuropathy associated with neoplasms. Muscle Nerve 2011;43(2):183-8.

5. Floyd JR 2nd, Keeler ER, Euscher ED, McCutcheon IE. Cyclic sciatica from extrapelvic endometriosis affecting the sciatic nerve. J Neurosurg Spine 2011;14(2):281-9.

6. Van Gompel JJ, Griessenauer CJ, Scheithauer BW, Amrami KK, Spinner RJ. Vascular malformations, rare causes of sciatic neuropathy: a case series. Neurosurgery 2010;67(4):1133-42.

7. lizuka S, Miura N, Fukushima T, Seki T, Sugimoto K, Inokuchi S. Gluteal compartment syndrome due to prolonged immobilization after alcohol intoxication: a case report. Tokai J Exp Clin Med 2011;36(2):25-8.

8. Mumby DM, Hartsilver EL. Magnetic resonance imaging of sciatic nerve compression injury after epidural blockade. Int J Obstet Anesth 2012;21(2):199-200.

9. Wang JC, Wong TT, Chen HH, Chang PY, Yang TF. Bilateral sciatic neuropathy as a complication of craniotomy performed in the sitting position: localization of nerve injury by using magnetic resonance imaging. Childs Nerv Syst 2012;28(1):159-63.

10. Sivrioglu AK, Ozyurek S, Mutlu H, Sonmez G. Piriformis syndrome occurring after pregnancy. BMJ Case Rep 2013;2013. 